\title{
The cognitive subscale of the "Alzheimer's Disease Assessment Scale" in a Brazilian sample
}

R.R. Schultz,

M.O. Siviero and P.H.F. Bertolucci
Setor de Neurologia do Comportamento, Departamento de Neurologia e Neurocirurgia, Escola Paulista de Medicina, Universidade Federal de São Paulo, São Paulo, SP, Brasil

\section{Correspondence \\ R.R. Schultz \\ Rua Botucatu, 591, Cj. 103 \\ 04023-062 São Paulo, SP \\ Brasil \\ Fax: + 55-11-5549-7109 ou 5549- \\ 4192 \\ E-mail: rrschultz@ hotmail.com}

Research supported by CAPES.

Publication supported by FAPESP.

Received May 30, 2000

Accepted July 12, 2001

\section{Abstract}

The cognitive subscale of the "Alzheimer's Disease Assessment Scale" (ADAS-Cog) is widely used for the evaluation of dementia and is very popular in dementia drug trials because of the characteristics of the scale. The objective of the present study was to adapt the ADAS$\mathrm{Cog}$ for use for the Brazilian population. A major problem is that education is variable, a fact that may influence performance in cognitive evaluation. This study was conducted on a control group (CG) of 96 subjects ( 25 males and 71 females aged $68 \pm 8.6$ years) and on 44 Alzheimer's disease (AD) patients (19 males and 25 females aged 72 \pm 6.4 years) with mild dementia (Clinical Dementia Rating score 1). For statistical analysis groups were divided into three educational levels: I, 0-4 years of schooling (65 CG/20 AD); II, 5-11 years of schooling (19 CG/7 AD), and III, 12 or more years of schooling (12 $\mathrm{CG} / 17 \mathrm{AD})$. The battery was applied according to original instructions. Total mean score for $\mathrm{CG}$ and $\mathrm{AD}$ was 10.9 and 22.9 for level I, 7.8 and 22.4 for level II, and 6.2 and 15.4 for level III, respectively. These results indicate that our version of the ADAS-Cog is useful to identify mild dementia, though there may be an overlapping when comparing high education demented with low education non-demented subjects.

\section{Introduction}

Although Alzheimer's disease (AD) has a great variety of symptoms, progressive memory loss and decline in other cognitive functions are its main characteristics. As the pathophysiology of the disease is becoming better understood, a strong interest in evaluating new drugs for treatment has also arisen. Therefore, efforts have been made to improve and standardize a methodology for the evaluation of different clinical trials (1-3).

The "Alzheimer's Disease Assessment Scale" (ADAS) was developed with the ob- jective of evaluating the intensity of cognitive and noncognitive changes which are characteristic of this disease. The scale is composed of two parts with a maximum score of 120 points. One is cognitive (ADAS$\mathrm{Cog}$ ) and includes items 1-11, with a maximum score of 70, while the other is noncognitive and assesses behavior disturbances, including items 12-21 with a maximum score of $50(4,5)$. The ADAS-Cog requires approximately 30 to $45 \mathrm{~min}$ to administer, according to the degree of cognitive impairment $(6,7)$. The main areas of the cognitive domains evaluated are memory (50\%), lan- 
guage (28\%), praxis (14\%) and command understanding (8\%) (8). A high score indicates a poor performance. The ADAS-Cog was not originally designed for use as a diagnostic instrument, but it was later proven that its scores clearly distinguished clinically diagnosed AD patients from non-dementia control subjects (7).

It was observed that the ADAS-Cog total score and its items are sensitive to the severity and degree of AD. For each 2.5 points, one point of worsening was observed in the Mini-Mental State Examination, for scores between 23 and 11 (7).

Longitudinal studies indicate that $\mathrm{AD}$ patients show an increase in the ADAS-Cog total score of 7 to 11 points per year (9).

After being successfully introduced as a primary evaluation instrument in the first double-blind multicenter study with tacrine (10), the ADAS-Cog has been used as the primary instrument to monitor the response to treatment of $\mathrm{AD}$ patients. Consequently, the scale has been adapted to several languages (11-17).

The objectives of the present study were to obtain a national ADAS-Cog standard by adapting it to the Portuguese language and to analyze the performance of a Brazilian sample in terms of gender, age and educational level, and the influence of these variables on the different ADAS-Cog items and on its total score.

Table 1. Educational level for the control group and Alzheimer's disease patients.

\begin{tabular}{lll}
\hline $\begin{array}{l}\text { Educational level } \\
\text { (years of schooling) }\end{array}$ & \multicolumn{1}{c}{ CG } & \multicolumn{1}{c}{ AD } \\
\hline $0-4$ & $\begin{array}{l}65(68 \%) \text { - } 17 \text { illiterate } \\
\text { subjects } \\
13 \text { males } / 52 \text { females }\end{array}$ & $\begin{array}{l}20(45 \%)-4 \text { illiterate subjects } \\
7 \text { males } / 13 \text { females }\end{array}$ \\
& $19(20 \%)$ & $7(16 \%)$ \\
5 -11 & $\begin{array}{l}\text { males } / 13 \text { females } \\
2 \text { males } / 5 \text { females }\end{array}$ & $17(39 \%)$ \\
12 or more & 11 males $/ 6$ females \\
& 6 males $/ 6$ females & 11 .
\end{tabular}

CG, control group; AD, Alzheimer's disease.

\section{Subjects and Method}

\section{Subjects}

A total of 140 subjects who took part in an open and prospective study were divided into two groups: 96 control subjects $(\mathrm{CG})$, 25 males and 71 females aged $68 \pm 8.6$ years (range, 50 to 87 years), and $44 \mathrm{AD}$ patients, 19 males and 25 females aged $72 \pm 6.4$ years (range, 54 to 83 years). Each group was subdivided into three educational levels: I, subjects with 0 to 4 years of schooling; II, subjects with 5 to 11 years of schooling, and III, 12 or more years of schooling (Table 1). The AD group consisted of individuals older than 50 years who met the criteria for the probable presence of $\mathrm{AD}$ according to the DSM-IV (18) and NINCDS-ADRDA (19). They were free of other neurological diseases and took no drugs which could interfere with the cognitive evaluation.

The aim was to study only patients with mild dementia, or dementia in its initial stages, who had a Clinical Dementia Rating (CDR) score of 1.0 (20) because they present a more difficult diagnostic challenge, may have a larger range of therapeutic alternatives and, consequently, present a greater possibility for improvement.

The CG consisted of subjects aged 50 years or older, spouse control volunteers and also other healthy elderly individuals from the community, who were free of neurological or psychiatric diseases and took no drugs which could interfere with the cognitive evaluation. Informed consent was obtained from CG subjects, all of whom had a CDR equal to 0 .

All subjects were free of severe and uncorrected visual or auditory deficits that could interfere with test performance.

\section{Method}

The ADAS-Cog was translated directly into Portuguese from the original English version. The structured evaluation was pre- 
ceded by an open-ended conversation with the objective of assessing various aspects of both expressive and receptive speech $(5,7$, 12,21). The scores of this evaluation were determined after the end of the test session, and they concern the following items: spoken language ability, word-finding difficulty in spontaneous speech, and comprehension. The ADAS-Cog scoring method is not difficult, but experience is needed for its application, especially for these three items (8).

\section{Statistical analysis}

Since data obtained for each variable were a skewed curve, it was not possible to use parametric tests. The following tests were applied to analyze the results: the MannWhitney test (22) was used to analyze the sex and age variables and the influence of education, comparing the AD patients with CG. Kruskal-Wallis (22) analysis of variance was used for comparison of the different educational levels in each group for similar items and age. When significant for items, this analysis was complemented by the multiple comparison test of Miller-Dunn (23).

\section{Battery}

The ADAS-Cog scale was applied by a neurologist according to the original instructions. The words for the items "immediate word recall" and "word recognition task" were modified for adaptation to the Portuguese language (see Appendix). Since, as far as we know, there is no frequency study for Brazilian Portuguese, we used a study on "familiarity and complexity" (24) with the following criteria: pairing low/high frequency words with low/high familiarity words, pairing for word extension, and preferably pairing for the same semantic category.

\section{Results}

No significant difference was observed for gender among $\mathrm{AD}$ patients and $\mathrm{CG}$ subjects for the different items or for the total score and further analysis did not consider this variable. A significant difference was observed for age in total subjects between groups and among AD patients and CG subjects for educational level between 5 and 11 years of schooling. No significant difference was observed for the age variable for other educational levels within or between groups. The influence of education was studied independently with comparisons between and within groups with reference to the items and corresponding educational levels (Table 2). Since we used only CDR 1.0 AD patients, for some items there was a ceiling effect in the sense that $\mathrm{CG}$ and $\mathrm{AD}$ patients did not make mistakes. No floor effect was observed. The total mean score for $\mathrm{CG}$ and $\mathrm{AD}$ was 10.9 and 22.9 for level I, 7.8 and 22.4 for level II, and 6.2 and 15.4 for level III, respectively. For all subitems the means, standard deviation and medians for each educational group are shown in Table 2. The high standard deviations observed for some subitems indicate the possibility of an overlap between groups. It should be noted that for the immediate word recall and total score subitems the performance within both groups was more homogeneous. In the $\mathrm{AD}$ patient group, considering the different educational levels, significant results were observed for the items commands, constructional praxis, comprehension and total score. For the CG, significance was observed in the items naming of objects and fingers, commands, constructional praxis, ideational praxis, remembering test instructions and total score. Between $\mathrm{CG}$ and $\mathrm{AD}$ subjects, when comparing the corresponding items in terms of the respective educational levels, the existence of significant differences was noted for educational level of 0 to 4 years of schooling in the items immediate word recall, constructional praxis, ideational praxis, orientation, word recognition and total score, with a better performance for CG. For 5 to 11 years 
of schooling, significance was noted in the items immediate word recall, ideational praxis, orientation, word recognition, comprehension and total score, with a better performance for $\mathrm{CG}$; while for 12 or more years of schooling significance was noted in the items immediate word recall, ideational praxis, orientation, word recognition, remembering test instructions and total score, with a better performance for CG.

Kruskal-Wallis analysis of variance showed differences between educational levels within groups in some items, i.e., commands and ideational praxis for CG; constructional praxis for $\mathrm{CG}$ and $\mathrm{AD}$; $\mathrm{CG}$ in total score of ADAS$\mathrm{Cog}$, subjects between 0 and 4 years of educa- tion were more significant than subjects between 5 and 11 and more than 12 years of education. For CG in items naming objects and fingers and remembering test instructions and $\mathrm{AD}$ patients in item commands, subjects between 0 and 4 years of education were more significant than subjects more than 12 years of education. For AD patients in item comprehension, subjects between 5 and 11 years of education were more significant than subjects between 0 and 4 years and more than 12 years of education. For AD patients in total score, subjects between 0 and 4 years and between 5 and 11 years of education were more significant than subjects with more than 12 years of education.

Table 2. Scores for the items of the cognitive subscale of the Alzheimer's Disease Assesment Scale (ADAS-Cog) obtained for a control group and for Alzheimer's disease patients with educational levels between 0 and 4 years of schooling ( $0-4$ Edu), 5 and 11 years of schooling ( 5 - 11 Edu) and 12 or more years of schooling (12+Edu).

\begin{tabular}{|c|c|c|c|c|c|c|}
\hline \multirow[t]{2}{*}{ Item } & \multicolumn{3}{|c|}{$\begin{array}{c}\text { Control group } \\
\text { [mean } \pm \text { SD (median)] }\end{array}$} & \multicolumn{3}{|c|}{$\begin{array}{l}\text { Alzheimer's disease } \\
\text { [mean } \pm \text { SD (median)] }\end{array}$} \\
\hline & $0-4$ Edu & 5-11 Edu & $12+E d u$ & $0-4$ Edu & 5-11 Edu & $12+E d u$ \\
\hline $\begin{array}{l}\text { Immediate word } \\
\text { recall }\end{array}$ & $3.9 \pm 1.4(4.0)^{*}$ & $3.9 \pm 1.3(3.0)^{*}$ & $3.4 \pm 0.8(4.0)^{*}$ & $6.1 \pm 1.1(6.0)^{*}$ & $6.4 \pm 1.4(7.0)^{*}$ & $5.4 \pm 1.2(6.0)^{*}$ \\
\hline $\begin{array}{l}\text { Naming objects and } \\
\text { fingers }\end{array}$ & $0.7 \pm 0.6(1.0)^{\#}$ & $0.4 \pm-(0)$ & $0.3 \pm-(0)^{\#}$ & $1.0 \pm 0.8(1.0)$ & $1.0 \pm-(1.0)$ & $0.4 \pm-(0)$ \\
\hline Commands & $0.8 \pm-(0)^{\#}$ & $0.3 \pm-(0)^{\#}$ & $0.1 \pm-(0)^{\#}$ & $1.1 \pm 1.0(1.0)^{\#}$ & $0.7 \pm-(0)$ & $0.4 \pm-(0)^{\#}$ \\
\hline $\begin{array}{l}\text { Constructional } \\
\text { praxis }\end{array}$ & $1.0 \pm 0.7(1.0)^{* \#}$ & $0.6 \pm-(0)^{\#}$ & $0.3 \pm-(0)^{\#}$ & $2.0 \pm 1.3(1.5)^{* \#}$ & $0.7 \pm 0.5(1.0)^{\#}$ & $0.4 \pm-(0)^{\#}$ \\
\hline Ideational praxis & $0.8 \pm 0.7(1.0)^{* \#}$ & $0.3 \pm-(0)^{* \#}$ & $0.1 \pm-(0)^{* \#}$ & $1.7 \pm-(1.5)^{*}$ & $1.3 \pm-(1.0)^{*}$ & $0.8 \pm-(1.0)^{*}$ \\
\hline Orientation & $0.5 \pm-(0)^{*}$ & $0.5 \pm-(0)^{*}$ & $0.3 \pm-(0)^{*}$ & $2.7 \pm 1.7(2.5)^{*}$ & $3.7 \pm 0.8(4.0)^{*}$ & $2.1 \pm 1.7(2.0)^{*}$ \\
\hline Word recognition & $2.4 \pm 2.1(2.0)^{*}$ & $1.7 \pm 1.6(1.0)^{*}$ & $1.8 \pm 1.3(1.0)^{*}$ & $6.7 \pm 2.9(6.5)^{*}$ & $6.1 \pm 2.0(7.0)^{*}$ & $4.9 \pm 3.2(4.0)^{*}$ \\
\hline $\begin{array}{l}\text { Remembering test } \\
\text { instructions }\end{array}$ & $0.7 \pm-(0)^{\#}$ & $0.3 \pm-(0)$ & $0 \pm-(0)^{* \#}$ & $1.8 \pm-(1.0)$ & $1.3 \pm-(1.0)$ & $0.7 \pm-(0)^{*}$ \\
\hline $\begin{array}{l}\text { Spoken language } \\
\text { ability }\end{array}$ & $0 \pm-(0)$ & $0 \pm-(0)$ & $0 \pm-(0)$ & $0.1 \pm-(0)$ & $0.3 \pm-(0)$ & $0.1 \pm-(0)$ \\
\hline $\begin{array}{l}\text { Word-finding difficulty } \\
\text { in spontaneous speech }\end{array}$ & $0 \pm-(0)$ & $0 \pm-(0)$ & $0 \pm-(0)$ & $0.1 \pm-(0)$ & $0.4 \pm-(0)$ & $0.1 \pm-(0)$ \\
\hline Comprehension & $0.1 \pm-(0)$ & $0 \pm-(0)^{*}$ & $0 \pm-(0)$ & $0.1 \pm-(0)^{\#}$ & $0.4 \pm-(0)^{* \#}$ & $0.1 \pm-(0)^{\#}$ \\
\hline $\begin{array}{l}\text { Total score of } \\
\text { ADAS-Cog }\end{array}$ & $10.9 \pm 6.2(10.0)^{* \#}$ & $7.8 \pm 2.8(8.0)^{* \#}$ & $6.3 \pm 2.4(5.5)^{* \#}$ & $23.0 \pm 7.5(22.5)^{* \#}$ & $22.4 \pm 5.0(21.0)^{* \#}$ & $15.4 \pm 5.0(16.0)^{* \#}$ \\
\hline
\end{tabular}

Data are reported as means \pm SD and medians are given in parentheses.

$* \mathrm{P}<0.05$ between groups for the same educational level;

\#p $<0.05$ within each group for different educational levels (Kruskal-Wallis test). 


\section{Discussion}

It is important to note that we did not examine variables such as vitamin use, estrogen replacement therapy and anti-inflammatory therapies, and it is possible that our control sample may have included patients with mild cognitive impairment.

Our data show significant differences between controls and AD patients in several items and in the total score of the ADASCog (Figure 1). It is important to stress that there is a large overlap between the AD and control groups.

There were no significant differences with respect to gender, a finding similar to that obtained in other reports $(13,17,25,26)$.

A lower educational level is related to a worse performance in the tests in most of the studies with ADAS (11,25,27-29). We observed that there is a significance in the education variable between and within groups. The items commands, constructional praxis and the total score of ADAS-Cog were equally significant in the $\mathrm{CG}$ and in the group with AD. The items immediate word recall, ideational praxis, orientation, word recognition and total score of ADAS-Cog were statistically significant in the three educational levels.

The literature demonstrates that the ADAS-Cog correlates well with other neuropsychological scales like the Mini-Mental State Examination (11,25,30-32), Global Deterioration Scale $(11,25,30)$, Geriatric Evaluation of Relative's Rating Instrument (25) and CDR (8).

We also believe that the battery is very useful in differentiating between normal in-

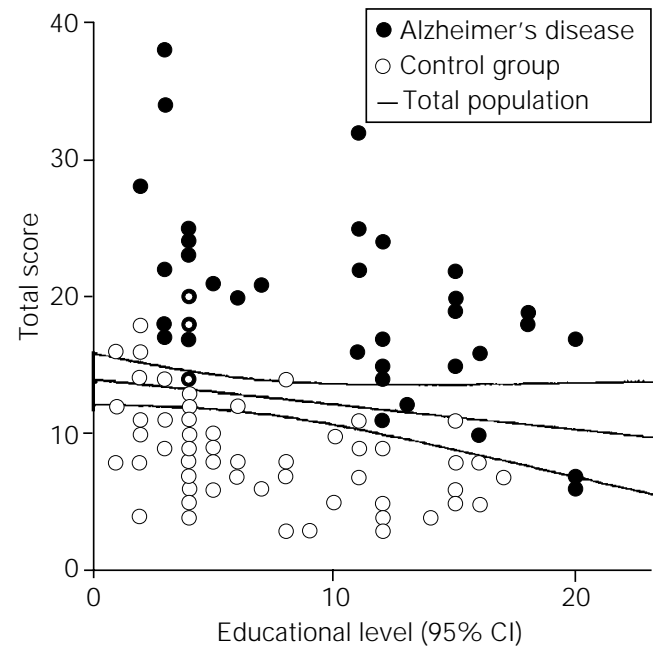

Figure 1. Performance in total score of the cognitive subscale of the "Alzheimer's Disease Assessment Scale" for years of educational level. $\mathrm{Cl}$, confidence interval. dividuals and mild $\mathrm{AD}$ patients.

We would like to stress that the variation shown by some subitems is an indication that the ADAS-Cog should be always applied as a complete battery, the isolated result of subitems having no meaning or leading to false negative/false positive results.

\section{Conclusions}

The educational level greatly influences the ADAS-Cog performance of the CG and the AD and CDR 1.0 patient group, as observed for different items of the test.

The present results indicate that the adaptation of the ADAS-Cog is adequate for our population when analyzed together with educational level.

This performance analysis permitted the differentiation between normal elderly individuals and AD patients using the ADASCog. 


\section{References}

1. Kluger A \& Ferris SH (1991). Scales for the assessment of Alzheimer's disease. Psychiatric Clinics of North America, 14: 309-326.

2. Ferris SH (1992). Diagnosis by specialists: psychological testing. Acta Neurologica Scandinavica, 139 (Suppl): 32-35.

3. Talwalker S, Overall JE, Srirama MK \& Gracon SI (1996). Cardinal features of cognitive dysfunction in Alzheimer's disease: a factor-analytic study of the Alzheimer's Disease Assessment Scale. J ournal of Geriatric Psychiatry and Neurology, 9: 39-46.

4. Rosen WG, Mohs RC \& Davis KL (1984). A new rating scale for Alzheimer's disease. American J ournal of Psychiatry, 141: 1356-1364.

5. Mohs RC \& Cohen L (1988). Alzheimer's Disease Assessment Scale (ADAS). Psychopharmacology Bulletin, 24: 627-628.

6. Schwarb S, Köberle S \& Spiegel R (1988). The Alzheimer's Disease Assessment Scale (ADAS): an instrument for early diagnosis of dementia? International J ournal of Geriatric Psychiatry, 3: 45-53.

7. Zec RF, Landreth ES, Vicari SK, Feldman E, Belman J , Andrise A, Robbs R, Kumar V \& Becker R (1992). Alzheimer's Disease Assessment Scale: useful for both early detection and staging of dementia of the Alzheimer type. Alzheimer Disease and Associated Disorders, 6: 89-102.

8. Zec RF, Landreth ES, Vicari SK, Belman J , Feldman E, Andrise A, Robbs R, Becker R \& Kumar V (1992). Alzheimer's Disease Assessment Scale: a subtest analysis. Alzheimer Disease and Associated Disorders, 6: 164-181.

9. Kramer-Ginsberg E, Mohs RC, Aryan M, Lobel D, Silverman J , Davidson M \& Davis KL (1988). Clinical predictors of course for Alzheimer patients in a longitudinal study: a preliminary report. Psychopharmacology Bulletin, 24: 458-462.

10. Davis KL, Thal LJ, Gamzu ER, Davis CS, Woolson RF, Gracon SI, Drachman DA, Schneider L, Whitehouse PJ , Hoover TM, Morris J C, Kawas CH, Knopman DS, Earl NL, Kumar V \& Doody RS (1992). A double-blind, placebo-controlled multicenter study of tacrine for Alzheimer's disease. New England J ournal of Medicine, 327: 1253-1259.

11. Mangone CA, de Pascale AM, Gigena VMG, Sanguinetti RM, Bauman PD, Pereyra S \& Sica REP (1995). Escala de evaluación para enfermedad de Alzheimer. Adaptación a la lengua castellana. Confiabilidad interexaminadores y en re- testeo seriado. Revista Neurologica Argentina, 20: 31-40.

12. Peña-Casanova J, Aguilar $M$, Santacruz $P$, Bertran-Serra I, Hernández G, Sol J M, Pujol A \& Blesa R (1997). Adaptación y normalización españolas de la Alzheimer's Disease Assessment Scale (ADAS) (NORMACODEM) (YII). Neurología, 12: 69-77.

13. Pascual LF, Saz P, Larumbe R, MartínezLage P, Muruzábal J, Morales F, Lobo A, Martínez-Lage J M \& Sastre y Hernández M (1997). Estandarización en una población española de la escala ADAS (Alzheimer's Disease Assessment Scale). Neurología, 12: 238-244.

14. Tsolaki M, Fountoulakis K, Nakopoulou E, Kazis A \& Mohs RC (1997). Alzheimer's Disease Assessment Scale: the validation of the scale in Greece in elderly demented patients and normal subjects. Dementia and Geriatric Cognitive Disorders, 8: 273280.

15. Puel M \& Hugonot-Diener I (1996). Présentation de l'adaptation en langue française par le groupe greco, d'une échelle d'évaluation cognitive utilisée dans les démences de type Alzheimer. Presse Médicale, 25: 1028-1032.

16. Homma A (1992). Assessment and treatment of patients with dementia of the Alzheimer's type. Nippon Ronen Igakkai Zasshi. J apanese J ournal of Geriatrics, 29: 264-270.

17. Weyer G, Erzigkeit H, Kanowski S, Ihl R \& Hadler D (1997). Alzheimer's Disease Assessment Scale: reliability and validity in a multicenter trial. International Psychogeriatrics, 9: 123-138.

18. American Psychiatric Association (1994). Diagnostic and Statistical Manual of Mental Disorders - DSM IV. 4th edn. W.B. Saunders, Washington, DC.

19. McKhann G, Drachman D, Folstein M, Katzman R, Price D \& Stadlan E (1984). Clinical diagnosis of Alzheimer's disease: report of the NINCDS-ADRDA work group under the auspices of department of health and human services task force on Alzheimer's disease. Neurology, 34: 939944.

20. Morris J C (1993). The Clinical Dementia Rating (CDR): current version and scoring rules. Neurology, 43: 2412-2414.

21. Raskind MA, Sadowsky $\mathrm{CH}$, Sigmund WR, Beitler PJ \& Auster SB (1997). Effect of tacrine on language, praxis, and noncognitive behavioral problems in Alzheimer's disease. Archives of Neurology, 54:
836-840.

22. Siegel S \& Castellan J r NJ (1988). Nonparametric Statistical Methods. 2nd edn. McGraw-Hill, New York.

23. Hollander M \& Wolfe DA (1973). Nonparametric Statistical Methods. Wiley-Liss, New York.

24. Pompéia $S, M$ iranda $M C \&$ Bueno OFA (2001). Conjunto de 400 figuras padronizadas para o português: normas de nomeação, familiaridade e complexidade visual para crianças e adultos. Arquivos de Neuro-Psiquiatria, 59: 330-337.

25. Doraiswamy PM, Bieber F, Kaiser L, Krishnan KR, Reuning-Scherer J \& Gulanski B (1997). The Alzheimer's Disease Assessment Scale: patterns and predictors of baseline cognitive performance in multicenter Alzheimer's disease trials. Neurology, 48: 1511-1517.

26. Stern RG, Mohs RC, Davidson M Schmeidler J, Silverman J, Kramer-Ginsberg $E$, Searcey $T$, Bierer $L \&$ Davis KL (1994). A longitudinal study of Alzheimer's disease: measurement, rate, and predictors of cognitive deterioration. American J ournal of Psychiatry, 151: 390-396.

27. Doraiswamy PM, Krishen MS, Stallone $F$, Martin WL, Potts NL, Metz A \& de Veaugh-Geiss J (1995). Cognitive performance on the Alzheimer's Disease Assessment Scale: effect of education. Neurology, 45: 1980-1984.

28. Peña-CasanovaJ (1997). Alzheimer's Disease Assessment Scale-Cognitive in clinical practice. International Psychogeriatrics, 9 (Suppl 1): 105-114.

29. Doraiswamy PM, Bieber F, Kaiser L, Connors K, Krishnan KR, Reuning-Scherer J \& Gulanski B (1997). Memory, language, and praxis in Alzheimer's disease: norms for outpatient clinical trial populations. Psychopharmacology Bulletin, 33: 123128.

30. Yesavage J A, Poulsen SL, Sheikh J \& Tanke E (1988). Rates of change of common measures of impairment in senile dementia of the Alzheimer's type. Psychopharmacology Bulletin, 24: 531-534.

31. Ihl R, Frölich L, Dierks T, Martin EM \& Maurer K (1992). Differential validity of psychometric tests in dementia of the Alzheimertype. Psychiatry Research, 44: 93-106.

32. Mattes J A (1997). Can the sensitivity of the Alzheimer's Disease Assessment Scale be increased? American J ournal of Geriatric Psychiatry, 5: 258-260. 
Appendix. The following items were analyzed:

1. Immediate word recall

In this task, the subject is given three tries to learn a list of ten words (see below). The subject must first read the words aloud, memorize them and then reproduce them. The subject's score is the average number of words not recalled in three trials (maximum 10).

\begin{tabular}{llllll}
\hline Trial 1 & & Trial 2 & & Trial 3 & \\
\hline Original list & Adapted list & Original list & Adapted list & Original list & Adapted list \\
\hline Home & Creme & Library & Flor & Army & Rei \\
Coin & Dedo & Flag & Casa & Wheat & Chá \\
Railroad & Mar & Home & Creme & Coin & Dedo \\
Child & Carta & Railroad & Mar & Flag & Casa \\
Army & Rei & Ocean & Motor & Skin & Poste \\
Flag & Casa & Coin & Dedo & Railroad & Mar \\
Skin & Poste & Army & Rei & Home & Creme \\
Library & Flor & Child & Carta & Ocean & Motor \\
Wheat & Chá & Skin & Poste & Library & Flor \\
Ocean & Motor & Wheat & Chá & Child & Carta \\
\hline
\end{tabular}

2. Naming objects and fingers

For this item the subject is asked to name the 12 real objects presented randomly as well as the fingers of his/her dominant hand. The objects presented were: flower, bed, whistle, pencil, rattle, mask, scissors, comb, wallet, harmonica, stethoscope, and tweezers. The score varies from 0 to 5 .

\section{Commands}

The subject is asked to carry out one to five commands. Score varies from 0 to 5 .

4. Constructional praxis

This task assesses the subject's ability to copy four geometric forms: a circle, a superimposed rectangle, a diamond and a square. Score varies from 0 to 4 .

5. Ideational praxis

This task is designed to determine whether the individual can perform a complex sequence of actions. The score varies from 0 to 5 .

6. Orientation

The components of this task are person, day of the week, day of the month, month, year, season, time of day and specific place. One point is given for each incorrect answer (maximum 8).

7. Word recognition

In this task, the subject must read and memorize a list of 12 words (in bold, see next page). These words are then randomly mixed with 12 words the subject has not seen, and the subject is asked to decide whether or not the word has already been read. The subject has three tries, in each of which, the word order is changed. The score is calculated by summing up the number of errors and dividing by $3 ; 12$ points is the maximum. 


\begin{tabular}{|c|c|c|c|c|c|}
\hline \multicolumn{2}{|l|}{ Trial 1} & \multicolumn{2}{|l|}{ Trial 2} & \multicolumn{2}{|l|}{ Trial 3} \\
\hline Original list & Adapted list & Original list & Adapted list & Original list & Adapted list \\
\hline Corn & Milho & River & Rio & Plant & Planta \\
\hline Effort & Esforço & Officer & Chefe & River & Rio \\
\hline Party & Festa & Thought & Plano & Amount & Total \\
\hline River & Rio & Event & Fato & Event & Fato \\
\hline Folly & Tolice & Queen & Dama & Queen & Dama \\
\hline Locker & Cofre & Position & Posição & Industry & Indústria \\
\hline Event & Fato & Camp & Campo & Position & Posição \\
\hline Queen & Dama & Fate & Fim & Occasion & Ocasião \\
\hline Position & Posição & Golf & Golfe & Dove & Siri \\
\hline Quality & Dom & Dove & Siri & Cradle & Berço \\
\hline Sunset & Entardecer & Belief & Fé & Banality & Bobagem \\
\hline Dove & Siri & Permission & Permissão & Singer & Cantor \\
\hline Belief & Fé & Umbrella & Sombrinha & Belief & Fé \\
\hline Umbrella & Sombrinha & Hint & Dica & Umbrella & Sombrinha \\
\hline Allegory & Ficção & Missile & Míssil & Hypothesis & Hipótese \\
\hline Hound & Cão & Blister & Bolha & Hint & Dica \\
\hline Idiom & Idioma & Concept & Noção & Missile & Míssil \\
\hline Hint & Dica & Proxy & Corretor & Proxy & Corretor \\
\hline Missile & Míssil & Pianist & Piano & Noose & Nó \\
\hline Gem & J óia & Lobster & Pomba & Distinction & Distinção \\
\hline Proxy & Corretor & Gender & Gênero & Lobster & Pomba \\
\hline Lobster & Pomba & Criterion & Critério & Tank & Tanque \\
\hline Criterion & Critério & Bullet & Tiro & Criterion & Critério \\
\hline Deceit & Erro & Intellect & Mente & Decree & Lei \\
\hline
\end{tabular}

8. Remembering test instructions

This item evaluates the individual's ability to remember the instructions of the recognition task. Score varies from 0 to 5 .

9. Spoken language ability

This item is an overall rating of the quality of speech, such as clarity and capacity to make someone understand. Score varies from 0 to 5.

10. Word-finding difficulty in spontaneous speech

This task analyzes the decrease in expressive speech, but only as refers to difficulty in word choice. Score varies from 0 to 5 .

11. Comprehension

This item evaluates the individual's ability to understand the examiner's speech. Score varies from 0 to 5 . 